Article

\title{
Evaluation of Energy Savings and Economic Benefits of SOLTAG Rooftop Extensions under the Conditions of a Model Area in the Slovak Republic
}

\author{
Daniela Spirkova ${ }^{1, *}$, Katarina Teplicka ${ }^{2} \mathbb{D}$, Sona Hurna ${ }^{3}$ and Robert Janiss ${ }^{1}$ \\ 1 Institute of Management, Slovak University of Technology in Bratislava, 81107 Bratislava, Slovakia; \\ janiss.robert@gmail.com \\ 2 Faculty of Mining, Ecology, Process Control and Geotechnologies, Technical University of Košice, \\ 04001 Košice, Slovakia; katarina.teplicka@tuke.sk \\ 3 Faculty of Business and Economics, Mendel University in Brno, 61300 Brno-sever-Černá Pole, Czech Republic; \\ sona.hurna@mendelu.cz \\ * Correspondence: daniela.spirkova@stuba.sk or spirkova.daniela@gmail.com; Tel.: +42-191-866-9110
}

check for

updates

Citation: Spirkova, D.; Teplicka, K.; Hurna, S.; Janiss, R. Evaluation of

Energy Savings and Economic

Benefits of SOLTAG Rooftop

Extensions under the Conditions of

a Model Area in the Slovak Republic.

Sustainability 2021, 13, 451.

https://doi.org/10.3390/su13020451

Received: 10 November 2020

Accepted: 27 December 2020

Published: 6 January 2021

Publisher's Note: MDPI stays neutral with regard to jurisdictional clai$\mathrm{ms}$ in published maps and institutional affiliations.

Copyright: $(\odot 2021$ by the authors. Licensee MDPI, Basel, Switzerland. This article is an open access article distributed under the terms and conditions of the Creative Commons Attribution (CC BY) license (https:// creativecommons.org/licenses/by/ $4.0 /)$.

\begin{abstract}
Modular building systems in the Slovak Republic are assessed as a practical construction method and solution for a particular type of housing stock, as well as an alternative. Most existing panel buildings designed in the Slovak Republic had sufficient static reserve, allowing for the construction of rooftop extensions. Despite the considerable advantages of modular rooftop extensions, the aforementioned method of increasing available and sustainable housing stock-especially in large cities-is under-utilized in Slovakia. This paper outlines a solution for low-energy extensions-the SOLTAG concept - on the basis of knowledge acquired by studying problems related to Soltag extensions as part of the SURE-Fit (Sustainable Roof Extension Retrofit) project and practical experience from Denmark. This paper aims to assess and compare energy savings and economic benefits for three rooftop extensions of the SOLTAG concept and bricked extensions for a model area in the Slovak Republic.
\end{abstract}

Keywords: environmental sustainability; sustainable construction of modular housing; housing economical sustainability

\section{Introduction}

Buildings energy consumption reduction can be considered as an innovative approach for housing construction and the future maintenance and renewal of housing stock. On the European scale, nearly $40 \%$ of power is used operating buildings, inside which we spend $90 \%$ of our time. This process generates increased user satisfaction with a healthy indoor environment and allows building design optimization. One of the very important environmental aims of the European Commission is to reduce the $\mathrm{CO}_{2}$ emissions produced by buildings. The newly released Directives (Energy Performance of Buildings Directive No. 844/2018) have already contributed to increased energy savings between $25 \%$ to $30 \%$ in some European countries [1]. In this article, we deal with suggesting a solution for low-energy extensions - the SOLTAG concept-on the basis of knowledge acquired by studying problems related to Soltag extensions as part of the SURE-Fit (Sustainable Roof Extension Retrofit) project and practical experiences from Denmark. The aim of this paper is to assess energy savings and economic benefits for three rooftop extensions of the SOLTAG concept and bricked extensions for a model area in the Slovak Republic. Prefabrication is often described as architecture's 'oldest new idea' for good reason. For decades prefabrication was viewed as the cutting edge of redefining design and construction-yet the potential has often not really taken off beyond prototypes. Prefabrication has a long history. The post-World War II era saw housing shortages and the emergence of novel forms of construction to meet this new challenge. Alongside conventionally produced 
housing built in an era of austerity, designers experimented with housing fabricated in factories or assembled from industrial components (for example, the Eames House), which relied on a range of novel structural and envelope technologies [2,3].

Newton et al. (2018) [4] note that since 1945 prefabrication helped to address skilled tradesman shortfalls in post-war Europe, whilst also addressing population growth due to the baby boom. In the 1960s, modular testing resulted in new prefabricated building projects [3]. For example, thousands of schools were built from prefabricated components in Western European countries after World War II and in the 1960s. These mass-produced and cheap buildings met the urgent need for new educational facilities [5]. The new millennium has brought many new technologies and ever-increasing user expectations for the higher quality and comfort of living. Central management systems as lighting, heating, and air conditioning provide more efficient operation and reduce optimization of energy consumption-SMART technologies [6].

Sustainable buildings are built using "sustainable" methods, materials, and practices to have the least negative impact on the surrounding ecosystem. Most are solar-oriented to form an optimal microclimate (longitudinal axis of a building should generally be oriented east-west) and provide natural shading and a wind barrier. Such construction considers daily/natural lighting and heating, creating zones with "thermal memory" that create a favorable microclimate.

Sustainable buildings have environmentally-friendly building materials that have been recycled and composted, non-toxic, renewable, recycled, and reclaimed materials, and materials developed and treated sustainably. Mostly local (regional) building materials and tools [7-9] are favored to reduce transport costs and pollution.

Higher savings could be achieved with the implementation of the current research focus: intelligent sensor networks bringing smart homes and smart cities together. Under test are processors, sensors, and network connectivity that may in the future perform management and technology in building and contributing to the optimization of urban resource utilization. The introduction (implementation) of intelligent home control systems, "green living" (environmentally-friendly), and "modular housing" need also be considered.

Modular housing is connected with real residents' needs which regard safety, availability of kindergartens, schools, health facilities, offices, and public transport. Modular design is $90 \%$ based on industrially pre-prepared elements. Quality unified elements allow, for example, that the material and facade appearance can be customized; some types of windows and doors can be used, which help achieve a high-quality connection between old and new elements. Another advantage is that the modular system can be combined with conventional design.

According to Lawson et al. (2014) [10], this new way of the building using prefabricated modular units leads to many constructional and sustainability benefits. However, the investment in the manufacturing process and in fixed facilities in a particular location requires an economy of scale to drive the financial benefits that accrue [3].

Modular construction, therefore, requires discipline among all members of the design and construction team to maximize the repetitive use of manufactured components, and to optimize the integrated design, supply, delivery, installation, and commissioning process. The benefits of modular construction may be focused on certain market sectors, where there is a demand for speed of construction, and economy in manufacture, or where reducing the disturbance of the building process is an important business or planning requirement. The main applications of modular construction may be summarized as the following:

- rooftop extensions to existing medium residential buildings as in Figure 1

- $\quad$ kindergarten as in Figure 2

- $\quad$ The concept of SOLTAG system Figure 3 


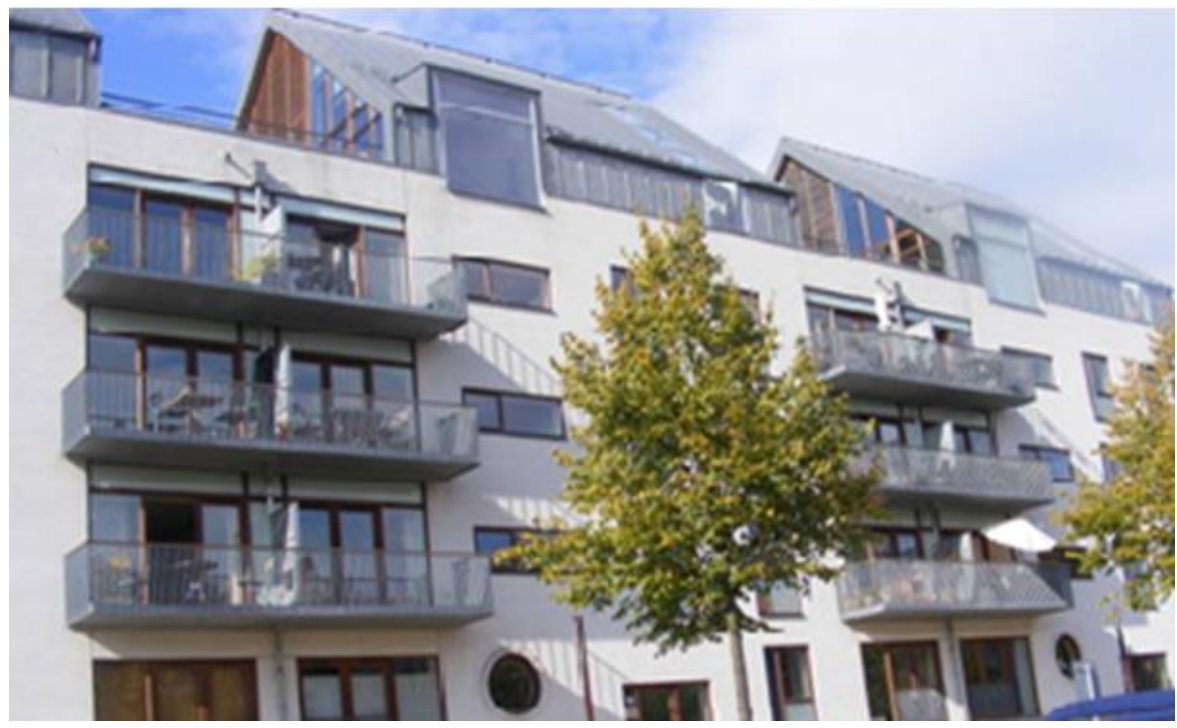

Figure 1. Roof extension by SOLTAG system in Copenhagen, Denmark (Source author).

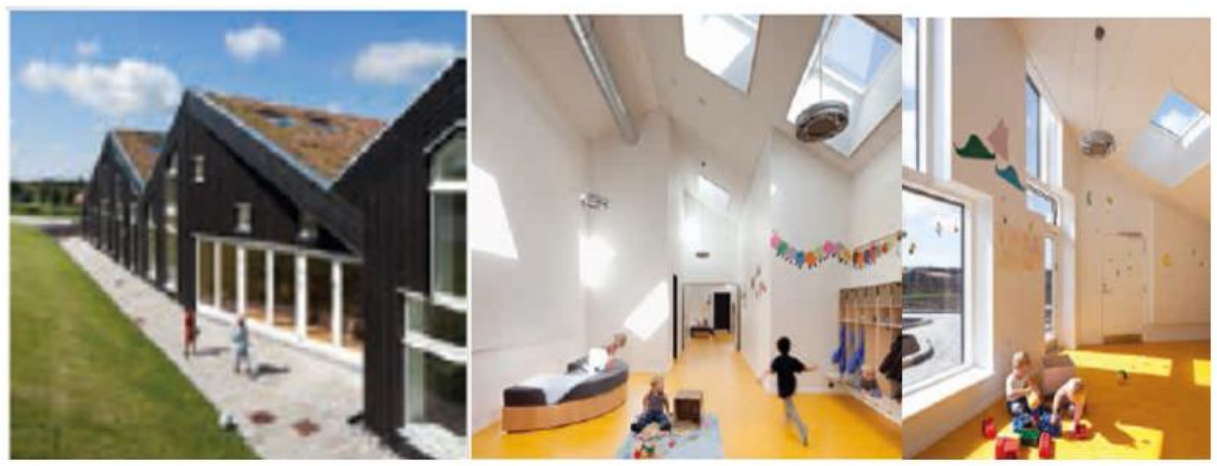

Figure 2. Kindergarten, Denmark Source Active house [11].
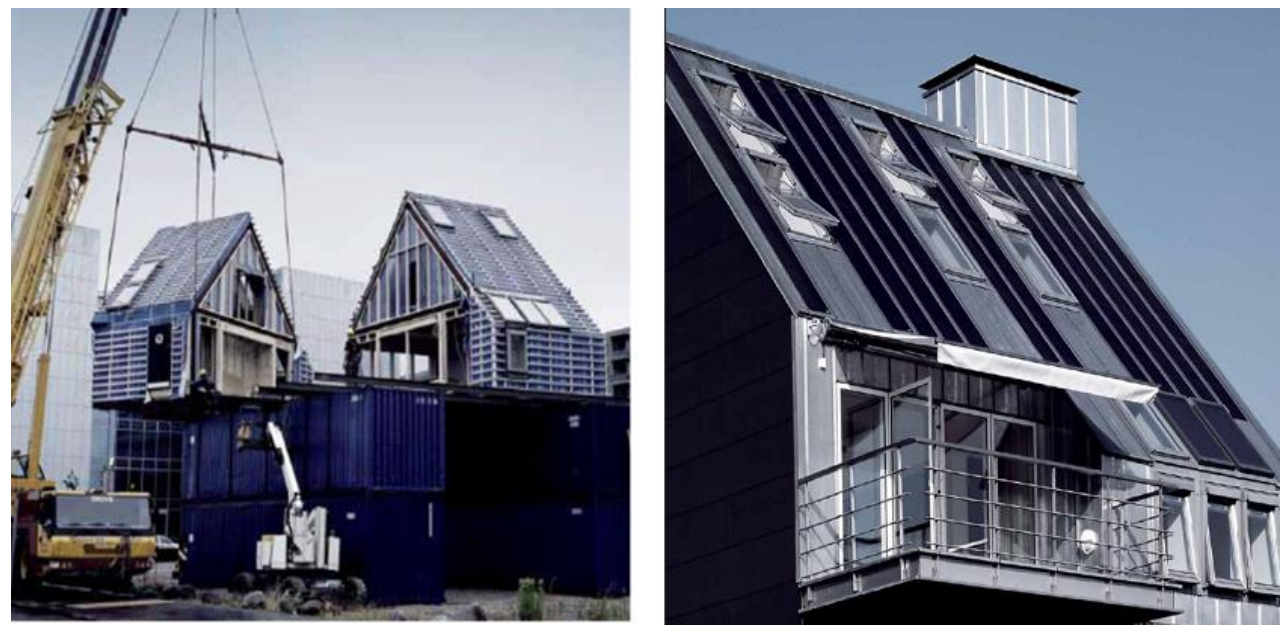

Figure 3. The concept of SOLTAG system Source Active house [11].

The response to demands for energy-efficiency and $\mathrm{CO}_{2}$-neutral housing of the future is the SOLTAG project, which is the result of research invention cooperation between a few European research institutes, universities departments, housing associations, and industrial enterprises engaged in the energy efficiency of buildings in the housing sector. The initiative originated in Denmark. There are some similar situations as in Slovakia 
because many buildings with flat roofs are from the 1960s and 1970s. The experimental solution itself originated with consideration of climate conditions in northern countries as in Norway, Denmark, and Finland, but might be a particular modification in some parts in Germany, the Czech Republic, or Slovakia concerning similar climate conditions. This system was designed as a flat module solution for the adaptation of a roof, which can be realized on existing residential buildings with flat roofs without the necessity to connect it to a building's current energy system. The project principles can also be used in new buildings [8,11].

This type of sample house was firstly constructed in 2005 as a part of the Demo-house research project in Denmark. A pair of prefabricated modules were used from a rooftop extension of the 1960s/1970s apartment buildings (Figure 1).

The next sample can be the kindergarten Soulhuset which is the way toward healthy and comfortable buildings where children can play, learn with plenty of daylight and fresh air (Figure 2).

The SOLTAG system (Figure 3), roof extensions was a part of the international project solution ANNEX 60-building restoration using prefabricated systems. The aim of this project was to the identification of advantages and options which was evaluated with using of prefabrication in the reconstruction process of existing residential buildings and to improve quality and accelerate measures that achieve the low-energy standard. The project considers approaches to reducing energy building consumption in Western Europe, where high expectations are placed on prefabricated systems, reducing the energy intensity of older buildings, and extending the building life cycle.

Roof building housing units on existing buildings meet contemporary criteria for housing reconstruction. It enables the extension of housing space in the building, allows modernization of the facilities, adaptation of the housing units to modern requirements, and allows the housing demand segmentation. The new housing unit construction does not require additional space, neither is sustainable in terms of land use. The new housing units do not need new foundations, materials are saved, construction waste is minimized, and material flow reduced. A rooftop extension also solves the problem unsuited for climates with frequent precipitation and icy winters, as leaking roofs then have to be repaired frequently. A sloping roof has a longer lifespan, can add additional architectural value to the refurbished building, and space under a sloping roof can be effectively used as an attic [8].

The strongest impacts from rooftop extensions can be achieved by a suitable combination of sustainability measures, renovation of the whole building, and energy efficiency measures connected with a housing market analysis. The identified situation in the housing market provides a source of new opportunities. For example, demand may exist for penthouses-high quality, non-standard modern homes that may cover more than one floor and may have a garden on the roof as well. The roofs of buildings are suitable for housing units especially when they have nice views. Refurbished buildings, together with the revitalization of the surrounding areas, have important positive external benefits for the area. The local market value of housing units in this place grows and a positive tenant mix can be achieved, although in some example gentrification may be expected. Furthermore, the bank providing the mortgage for the client's rooftop extensions should also benefit from the rising property value, which allows them to reduce their mortgage risk [6].

Comprehensive reconstruction also provides an opportunity to make existing housing stocks better by enlarging balconies or upgrading the facade. Additional housing units may also help solve some family housing problems. Older family members may have a different need for less space for living because their children have flown the nest but they want to stay in their familiar neighborhood. So, if they can move to new smaller rooftop housing units they can be satisfied. Many high-rise buildings need renovation and are often situated in attractive urban areas close to the city center or in a relatively quiet and environmentally acceptable environment. After a reconstruction, their value can substantially increase. 
New housing units atop buildings can become an interesting revenue source for housing owners. From such revenues, the costs of the older refurbished part of the building can be covered. This option is especially important in the case of social housing as well as condominiums. In Eastern European countries, people often lack the necessary financial resources to pay the full costs of building renovation. Revenues from selling a rooftop extension can become one of the additional sources of financing such reconstruction and can reduce the financial burden.

An important initiative in the field of the refurbishment of panel housing is the SUREFit (Sustainable Roof Extension Retrofit) project financed by the European Commission. The mentioned project is a part of the Intelligent Energy Program. The project focused on rooftop extension retrofits for high-rise social housing in Europe and researchers who participated were from the Netherlands, France, Germany, Italy, Slovakia, the Czech Republic, Poland, Sweden, and Denmark. The main goals were:

- the consolidation of existing new technologies and best practices of rooftop extension retrofit for high-rise social housing, and to develop process models and custom-made guidelines for broader implementation of the innovative solution in Europe,

- the dissemination of knowledge and promotion of the integration of small-scale RES (renewable energy systems) installations, particularly PV panels, into rooftop extension retrofits for high-rise social housing in Europe.

Rooftop extensions, as are defined in the mentioned project, may overcome and solve several problems of high-rise buildings. First, it allows the funding of their comprehensive refurbishment. Selling a new additional housing unit on the rooftop creates important additional financial sources for the refurbishment of the whole multiple-family building, lowering the financial burden for existing owners. The use of innovative technologies, such as better insulation materials, photovoltaic (PV) modules, etc. enables energy-neutral housing units to be built on top of existing buildings. These approaches save resources.

An important aspect of the retrofit scheme is the intelligent flexible design (IFD) of new housing units. This approach includes:

- a smart, systemized approach of producing and delivering affordable and convenient rooftop extensions,

- waste reduced (re-use of existing building structures, possible re-use of demountable and modular IFD components),

- Less repair and maintenance required over the building's life cycle.

The refurbished building may stimulate urban improvement as a joint effort between the local authority, housing associations, market parties, and residents [12].

The low energy concept is at this time a way that helps to reduce buildings' energy consumption. This technology requires strict requirements for theoretical project preparation-proper selection of building components, and observance of technological processes and quality assurance procedures of construction.

SOLTAG project is a complex project in the use of prefabricated systems concept, which uses an energy roof that integrates sunlight with photovoltaic cells. The system is focused on the achievement of a balance between heat gain, insulation capacity, and air exchange. Thus is a reason why a designed building can be described as an "energy production plant", which in addition to savings also has a pleasing and healthy indoor environment [11].

The objective of this paper is to assess and compare the energy savings and economic contributions for three variants (types) of the prefabricated system of SOLTAG solar houses: SOLTAG 1 (low energy level), SOLTAG 2 (passive level), and SOLTAG 3 (nearly zero energy needs). Based on the comparative analysis of costs of bricked and SOLTAG extension, the economic return will be subsequently assessed. Calculations are done based on the valid technical standards in the Slovak Republic. 


\section{Materials and Methods}

The paper used the statistical data and analyses done by Eurostat and the Statistical Office of the Slovak Republic. On the basis of Eurostat statistical data, we concluded that on average about 1954 new housing units in Slovakia are built as rooftop extensions, annexes, and build-ones-typical for both residential buildings and family houses. The ratio of newly built housing units in residential and family houses is $46.5 / 54.5$, while the ratio of additional buildings and structures in residential buildings is practically negligible. An analysis of the above data and subsequent conversion shows the number of new housing units built as rooftop extensions comprised approximately 900 flats per year (46.5\% from 1954).

Calculation methods were processed by the standards:

- $\quad$ STN 73 0540-3, Properties of environment and building products-Parts 3: Thermal performance of buildings and constructions. Thermal protection of buildings. Bratislava, Slovak Standards Institute [12]

- $\quad$ STN 73 0540-4, Calculation methods-Parts 4: Thermal performance of buildings and constructions. Thermal protection of buildings. Bratislava, Slovak Standards Institute 2002 [13]

- $\quad$ STN 73 0540-2, Functional requirements-Parts 2: Thermal performance of buildings and constructions. Thermal protection of buildings. Bratislava, Slovak Standards Institute 2002 [14].

Calculations were processed for three variants (types) of SOLTAG solar houses. The potential savings of energy of newly constructed housing units is in Table 1.

Table 1. The potential savings of energy of newly constructed housing units.

\begin{tabular}{|c|c|c|c|c|c|c|c|c|}
\hline \multirow[t]{2}{*}{ Measure } & \multicolumn{2}{|c|}{$\begin{array}{c}\text { Low Energy } \\
\text { Level-50 } \\
\mathrm{kWh} / \mathrm{m}^{2}\end{array}$} & \multicolumn{5}{|c|}{ Ultra-Low Energy Level-25 kWh/m ${ }^{2}$} & \multirow{2}{*}{$\begin{array}{c}\begin{array}{c}\text { Buildings with Nearly } \\
\text { Zero Energy Consumption } \\
\mathbf{1 2 . 5} \mathbf{~ k W h} / \mathbf{m}^{\mathbf{2}}\end{array} \\
2021 \\
\end{array}$} \\
\hline & 2014 & 2015 & 2016 & 2017 & 2018 & 2019 & 2020 & \\
\hline \multicolumn{9}{|l|}{$\begin{array}{c}\text { Potential for energy } \\
\text { savings: }\end{array}$} \\
\hline $\begin{array}{l}\text { (a) number } \\
\text { of rooftop extensions }\end{array}$ & 900 & 900 & 900 & 900 & 900 & 900 & 900 & 900 \\
\hline $\begin{array}{l}\text { (b) heat energy } \\
\text { demand }\end{array}$ & $\begin{array}{l}13.61 \\
\text { TJ/ } \\
\text { year }\end{array}$ & $\begin{array}{c}13.61 \\
\mathrm{TJ} / \\
\text { year }\end{array}$ & $\begin{array}{l}6.8 \mathrm{TJ} / \\
\text { year }\end{array}$ & $\begin{array}{l}6.8 \mathrm{TJ} / \\
\text { year }\end{array}$ & $\begin{array}{l}6.8 \mathrm{TJ} / \\
\text { year }\end{array}$ & $\begin{array}{l}6.8 \mathrm{TJ} / \\
\text { year }\end{array}$ & $\begin{array}{l}6.8 \mathrm{TJ} / \\
\text { year }\end{array}$ & $\begin{array}{l}3.4 \mathrm{TJ} / \\
\text { year }\end{array}$ \\
\hline Soltag type & \multicolumn{2}{|c|}{$\begin{array}{c}\text { Soltag } 1-30 \\
\mathrm{kWh} / \mathrm{m}^{2}\end{array}$} & \multicolumn{5}{|c|}{ Soltag 2-heat energy demand $15.2 \mathrm{kWh} / \mathrm{m}^{2}$} & Soltag $3-4 \mathrm{kWh} / \mathrm{m}^{2}$ \\
\hline $\begin{array}{l}\text { (a) heat energy } \\
\text { demand }\end{array}$ & $\begin{array}{l}8.15 \mathrm{TJ} / \\
\text { year }\end{array}$ & $\begin{array}{c}8.15 \mathrm{TJ} / \\
\text { year }\end{array}$ & $\begin{array}{c}4.14 \mathrm{TJ} / \\
\text { year }\end{array}$ & $\begin{array}{l}4.14 \mathrm{TJ} / \\
\text { year }\end{array}$ & $\begin{array}{l}4.14 \mathrm{TJ} / \\
\text { year }\end{array}$ & $\begin{array}{c}4.14 \mathrm{TJ} / \\
\text { year }\end{array}$ & $\begin{array}{l}4.14 \mathrm{TJ} / \\
\text { year }\end{array}$ & $\begin{array}{l}1.1 \mathrm{TJ} / \\
\text { year }\end{array}$ \\
\hline (b) annual saving & $\begin{array}{l}5.46 \mathrm{TJ} / \\
\text { year }\end{array}$ & $\begin{array}{l}5.46 \mathrm{TJ} / \\
\text { year }\end{array}$ & $\begin{array}{l}2.66 \mathrm{TJ} / \\
\text { year }\end{array}$ & $\begin{array}{c}2.66 \mathrm{TJ} / \\
\text { year }\end{array}$ & $\begin{array}{c}2.66 \mathrm{TJ} / \\
\text { year }\end{array}$ & $\begin{array}{l}2.66 \mathrm{TJ} / \\
\text { year }\end{array}$ & $\begin{array}{l}2.66 \mathrm{TJ} / \\
\text { year }\end{array}$ & $\begin{array}{l}2.3 \mathrm{TJ} / \\
\text { year }\end{array}$ \\
\hline $\begin{array}{l}\text { (c) annual increase } \\
\text { of savings }\end{array}$ & & $10.92 \mathrm{TJ}$ & $13.58 \mathrm{TJ}$ & $16.24 \mathrm{TJ}$ & $18.9 \mathrm{TJ}$ & $21.56 \mathrm{TJ}$ & $24.22 \mathrm{TJ}$ & $26.52 \mathrm{TJ}$ \\
\hline
\end{tabular}

Source: Own processing.

1. SOLTAG 1 (low energy level) — a house using only passive sunlight-heat energy demand $30 \mathrm{kWh} / \mathrm{m}^{2}$ (Act. no. 555/2005),

2. SOLTAG 2 (passive level) - a house using solar panels and photovoltaic roof panels (surface area $3.5 \mathrm{~m}^{2}$ )—heat energy demand $15.2 \mathrm{kWh} / \mathrm{m}^{2}$ (Act. no. 555/2005),

3. SOLTAG 3 (nearly zero energy needs) - a house using solar panels and photovoltaic roof panels (area of $17.5 \mathrm{~m}^{2}$ ) — heat energy demand $0 \mathrm{kWh} / \mathrm{m}^{2}$-zero or even positive energy house (self-sufficient house) (Act. no. 555/2005). 
Calculation method [9-11]:

1. The living space of SOLTAG rooftop extensions is $84 \mathrm{~m}^{2}=1$ housing unit.

2. SOLTAG 1 (low energy level $=30 \mathrm{kWh} / \mathrm{m}^{2}$ ).

3. Living space built in Slovakia per year $=900 \times 84=75,600 \mathrm{~m}^{2}$.

4. Total energy consumption of newly built rooftop extensions in a particular year $=75,600 \mathrm{~m}^{2} \times 30 \mathrm{kWh} / \mathrm{m}^{2}=2,268,000 \mathrm{kWh} /$ year $=8.15 \mathrm{TJ}$.

Energy intensity $=$ number of rooftop extensions per year $\mathrm{x}$ floor surface $\mathrm{x}$ energy intensity of housing unit

Energy intensity $($ SOLTAG 1$)=900 \mathrm{pcs} \times 84 \times 30 \mathrm{~m}^{2}(15.2)(4) \mathrm{kWh} / \mathrm{m}^{2}$.

5. Restrictions of the rules and laws of the Slovak Republic [15] are also considered in the construction of rooftop extensions SOLTAG type 2 (passive standard) and SOLTAG 3 (zero or positive energy building).

6. Values of energy intensity of rooftop extensions were compared with rooftop extensions that have been made in the standard (solid-masonry) way, according to current standards in the Slovak Republic.

7. Here we did likewise, but we considered data regarding the energy intensity of rooftop extensions on the basis of existing legislation (building low energy buildings $50 \mathrm{kWh} / \mathrm{m}^{2}$ ) and EU regulations on reducing the energy intensity of buildings (from 2016 - ultra low energy buildings- $25 \mathrm{kWh} / \mathrm{m}^{2}$ and from 2021 construction of nearly zero energy consumption- $12.5 \mathrm{kWh} / \mathrm{m}^{2}$ ).

The implementation of a rooftop extension with standard masonry type in the Slovak Republic is shown in the following example:

Energy intensity $=900 \mathrm{pcs} \times 84 \mathrm{~m}^{2} \times 50 \mathrm{kWh} / \mathrm{m}^{2}=3,780,000 \mathrm{kWh} /$ year $=13.61 \mathrm{TJ}$.

Low energy level-it means $50 \mathrm{kWh} / \mathrm{m}^{2}$

Ultra-low energy level-it means $25 \mathrm{kWh} / \mathrm{m}^{2}$

Zero energy consumption-it means $12.5 \mathrm{kWh} / \mathrm{m}^{2}$

Consequently, the annual saving is calculated as the difference between the heat consumption for heating standard building construction and the SOLTAG construction systems.

$$
\text { Example: Annual saving }=13.61 \mathrm{TJ}-8.15=5.46 \mathrm{TJ}
$$

In line c-the annual increase of savings, individual annual savings are calculated that will be achieved from 2014 to 2021, resulting in total savings of $26.52 \mathrm{TJ}$.

\section{Results and Discussion}

The ideal number of floors of existing residential buildings intended for rooftop extensions in our opinion is in the range of 2-5 floors, with regards to the feasibility of using cranes, and built in the period 1946 to 1990 (see Table 2). Based on the statistics, we can state that in Slovakia the number of such suitable buildings (in theory it also depends on the overall technical condition of the building) is 31,899 . If we consider that on average eight housing units can be built on every residential building, the number of the total built housing units in Slovakia is 255,192. The European Commission is calling for a reduction of energy consumption in buildings in the field of energy efficiency and is setting standards that must be met. These standards represent the limit values (Table 3) that buildings must adhere to save energy consumption. The standardized calculation is linked to the standards set by the legislation [16]. 
Table 2. Number of built residential buildings.

\begin{tabular}{|c|c|c|c|c|c|c|}
\hline \multirow{2}{*}{ Flats According to Number of Floors } & \multicolumn{5}{|c|}{ The Year of Construction of Residential Building } & \multirow{2}{*}{ Total } \\
\hline & $1946-1960$ & 1961-1970 & 1971-1980 & 1981-1985 & 1986-1990 & \\
\hline 2 & 1995 & 1436 & 1430 & 321 & 219 & 5401 \\
\hline 3 & 4752 & 1984 & 2049 & 626 & 436 & 9847 \\
\hline 4 & 2320 & 4068 & 4697 & 1054 & 324 & 12,463 \\
\hline 5 & 641 & 1720 & 1263 & 410 & 154 & 4188 \\
\hline Residential buildings built in total & 9708 & 9208 & 9439 & 2411 & 1133 & 31,899 \\
\hline
\end{tabular}

Source: Own calculations according to data from the Statistical Office of the Slovak Republic.

Table 3. Normalized values for new residential buildings.

\begin{tabular}{cccc}
\hline \multicolumn{3}{c}{ Standard and Recommended Values of Heat Necessary to Achieve EHB in $\mathbf{k W h} /\left(\mathrm{m}^{2}\right)$} \\
\hline Building Category & $\begin{array}{c}\text { Low Energy Buildings } \\
\text { from 2013 }\end{array}$ & $\begin{array}{c}\text { Ultra-Low Energy Buildings } \\
\text { from 2016 }\end{array}$ & $\begin{array}{c}\text { Buildings with Nearly Zero } \\
\text { Energy Consumption } \\
\text { from 2021 }\end{array}$ \\
\hline Family houses & 81.4 & 40.7 & 20.4 \\
\hline Residential buildings & 50.0 & 25.0 & 12.5 \\
\hline
\end{tabular}

\subsection{Energy Savings of SOLTAG Rooftop Extensions}

\subsubsection{Example No. 1}

If SOLTAG rooftop extensions are implemented in accordance with the regulations of the Slovak Republic. The potential savings can be seen in Table 1 and in conformity with the model for reducing the energy consumption of buildings as shown in Table 3.

Achieved savings compared to conventional rooftop extensions implemented in the standard (masonry) way are $26.52 \mathrm{TJ} /$ year from 2014 to 2021. Demand for the heating of rooftop extensions made from blocks and a brick according to energy standards and directives of the Slovak Republic is $64.62 \mathrm{TJ}$ for the period from 2014 to 2021. The heating demand of superstructures using the SOLTAG 1 construction system (low energy level), SOLTAG 2 (passive standard), and SOLTAG 3 (nearly zero energy needs) is 38.1 TJ. Total savings are $41 \%$.

\subsubsection{Example No. 2}

If SOLTAG rooftop extensions are implemented in the passive energy standard (SOLTAG 2), from 2021 buildings would be constructed with nearly zero energy consumption as per the directives of energy efficiency of buildings, we can see potential savings in Table 4.

Achieved savings compared to the conventional superstructure (masonry) are $34.54 \mathrm{TJ} /$ year from 2014 to 2021. Demand for heating of rooftop extensions made from blocks and brick as per the energy standards and directives of the Slovak Republic is $64.62 \mathrm{TJ}$ for the period from 2014 to 2021. The heating demand of superstructures implemented using the SOLTAG 2 construction system (passive standard) and SOLTAG 3 (buildings with nearly zero energy needs) is $30.08 \mathrm{TJ}$. Total savings are $53.5 \%$. 
Table 4. Potential energy savings to heat newly constructed housing units by the implementation of rooftop extensions in the passive energy standard SOLTAG 2.

\begin{tabular}{|c|c|c|c|c|c|c|c|c|}
\hline \multirow[t]{2}{*}{ Measure } & \multicolumn{2}{|c|}{$\begin{array}{c}\text { Low Energy } \\
\text { Level-50 } \\
\mathrm{kWh} / \mathrm{m}^{2}\end{array}$} & \multicolumn{5}{|c|}{ Ultra-Low Energy Level-25 kWh/m $\mathrm{m}^{2}$} & \multirow{2}{*}{$\begin{array}{c}\text { Buildings with Nearly } \\
\text { Zero Energy } \\
\text { Consumption-12.5 } \\
\text { kWh/m }{ }^{2}\end{array}$} \\
\hline & 2014 & 2015 & 2016 & 2017 & 2018 & 2019 & 2020 & \\
\hline \multicolumn{9}{|l|}{$\begin{array}{c}\text { Potential of energy } \\
\text { savings: }\end{array}$} \\
\hline $\begin{array}{l}\text { (a) number of } \\
\text { rooftop extensions }\end{array}$ & 900 & 900 & 900 & 900 & 900 & 900 & 900 & 900 \\
\hline $\begin{array}{l}\text { (b) heat energy } \\
\text { demand }\end{array}$ & $\begin{array}{c}13.61 \\
\text { TJ/year }\end{array}$ & $\begin{array}{c}13.61 \\
\text { TJ/year }\end{array}$ & $\begin{array}{c}6.8 \\
\text { TJ/year }\end{array}$ & $\begin{array}{c}6.8 \\
\text { TJ/year }\end{array}$ & $\begin{array}{c}6.8 \\
\text { TJ/year }\end{array}$ & $\begin{array}{c}6.8 \\
\text { TJ/year }\end{array}$ & $\begin{array}{c}6.8 \\
\text { TJ/year }\end{array}$ & $3.4 \mathrm{TJ} /$ year \\
\hline Soltag type & \multicolumn{7}{|c|}{ Soltag 2-heat energy demand $15.2 \mathrm{kWh} / \mathrm{m}^{2}$} & Soltag $3-4 \mathrm{kWh} / \mathrm{m}^{2}$ \\
\hline $\begin{array}{l}\text { (a) heat energy } \\
\text { demand }\end{array}$ & $\begin{array}{c}4.14 \\
\text { TJ/year }\end{array}$ & $\begin{array}{c}4.14 \\
\text { TJ/year }\end{array}$ & $\begin{array}{c}4.14 \\
\text { TJ/year }\end{array}$ & $\begin{array}{c}4.14 \\
\text { TJ/year }\end{array}$ & $\begin{array}{c}4.14 \\
\text { TJ/year }\end{array}$ & $\begin{array}{c}4.14 \\
\text { TJ/year }\end{array}$ & $\begin{array}{c}4.14 \\
\text { TJ/year }\end{array}$ & $1.1 \mathrm{TJ} /$ year \\
\hline (b) annual saving & $\begin{array}{c}9.47 \\
\mathrm{TJ} / \text { year }\end{array}$ & $\begin{array}{c}9.47 \\
\mathrm{TJ} / \text { year }\end{array}$ & $\begin{array}{c}2.66 \\
\text { TJ/year }\end{array}$ & $\begin{array}{c}2.66 \\
\text { TJ/year }\end{array}$ & $\begin{array}{c}2.66 \\
\mathrm{TJ} / \text { year }\end{array}$ & $\begin{array}{c}2.66 \\
\mathrm{TJ} / \text { year }\end{array}$ & $\begin{array}{c}2.66 \\
\text { TJ/year }\end{array}$ & $2.3 \mathrm{TJ} /$ year \\
\hline $\begin{array}{c}\text { (c) annual increase } \\
\text { of savings }\end{array}$ & & $18.94 \mathrm{TJ}$ & $21.6 \mathrm{TJ}$ & $24.26 \mathrm{TJ}$ & $26.92 \mathrm{TJ}$ & $29.58 \mathrm{TJ}$ & $32.24 \mathrm{TJ}$ & $34.54 \mathrm{TJ}$ \\
\hline
\end{tabular}

\subsubsection{Example No. 3}

If SOLTAG rooftop extensions are implemented to the standard of nearly zero energy needs from 2014, we can say that potential savings would be much higher. In Table 5, we can see achieved savings that result from the implementation of SOLTAG type 3 rooftop extensions.

Table 5. Potential energy savings to heat newly constructed housing units through rooftop extensions of residential buildings.

\begin{tabular}{|c|c|c|c|c|c|c|c|c|}
\hline \multirow[t]{2}{*}{ Measure } & \multicolumn{2}{|c|}{$\begin{array}{c}\text { Low Energy } \\
\text { Level-50 } \\
\mathrm{kWh} / \mathrm{m}^{2}\end{array}$} & \multicolumn{5}{|c|}{ Ultra-Low Energy Level-25 kWh/m ${ }^{2}$} & \multirow{2}{*}{$\begin{array}{c}\begin{array}{c}\text { Buildings with Nearly } \\
\text { Zero Energy } \\
\text { Consumption-12.5 } \\
\text { kWh/m }{ }^{2}\end{array} \\
2021\end{array}$} \\
\hline & 2014 & 2015 & 2016 & 2017 & 2018 & 2019 & 2020 & \\
\hline \multicolumn{9}{|l|}{$\begin{array}{c}\text { Potential of energy } \\
\text { savings: }\end{array}$} \\
\hline $\begin{array}{l}\text { (a) number of } \\
\text { rooftop extensions } \\
\text { (flats) }\end{array}$ & 900 & 900 & 900 & 900 & 900 & 900 & 900 & 900 \\
\hline $\begin{array}{l}\text { (b) heat energy } \\
\text { demand }\end{array}$ & $\begin{array}{c}13.61 \\
\text { TJ/year }\end{array}$ & $\begin{array}{c}\text { 13..61 } \\
\text { TJ/year }\end{array}$ & $\begin{array}{c}6.8 \\
\text { TJ/year }\end{array}$ & $\begin{array}{c}6.8 \\
\text { TJ/year }\end{array}$ & $\begin{array}{c}6.8 \\
\text { TJ/year }\end{array}$ & $\begin{array}{c}6.8 \\
\text { TJ/year }\end{array}$ & $\begin{array}{c}6.8 \\
\text { TJ/year }\end{array}$ & $3.4 \mathrm{TJ} /$ year \\
\hline Soltag type & \multicolumn{8}{|c|}{ Soltag 3-heat energy demand-4 kWh $/ \mathrm{m}^{2}$} \\
\hline $\begin{array}{l}\text { (a) heat energy } \\
\text { demand }\end{array}$ & $\begin{array}{c}1.1 \\
\text { TJ/year }\end{array}$ & $\begin{array}{c}1.1 \\
\text { TJ/year }\end{array}$ & $\begin{array}{c}1.1 \\
\mathrm{TJ} / \text { year }\end{array}$ & $\begin{array}{c}1.1 \\
\text { TJ/year }\end{array}$ & $\begin{array}{c}1.1 \\
\text { TJ/year }\end{array}$ & $\begin{array}{c}1.1 \\
\text { TJ/year }\end{array}$ & $\begin{array}{c}1.1 \\
\text { TJ/year }\end{array}$ & $1.1 \mathrm{TJ} /$ year \\
\hline (b) annual saving & $\begin{array}{c}12.51 \\
\text { TJ/year }\end{array}$ & $\begin{array}{c}12.51 \\
\text { TJ/year }\end{array}$ & $\begin{array}{c}5.7 \\
\text { TJ/year }\end{array}$ & $\begin{array}{c}5.7 \\
\text { TJ/year }\end{array}$ & $\begin{array}{c}5.7 \\
\text { TJ/year }\end{array}$ & $\begin{array}{c}5.7 \\
\text { TJ/year }\end{array}$ & $\begin{array}{c}5.7 \\
\text { TJ/year }\end{array}$ & $2.3 \mathrm{TJ} /$ year \\
\hline $\begin{array}{c}\text { (c) annual increase } \\
\text { of savings }\end{array}$ & & $25.02 \mathrm{TJ}$ & $30.72 \mathrm{TJ}$ & $36.42 \mathrm{TJ}$ & $42.12 \mathrm{TJ}$ & $47.82 \mathrm{TJ}$ & $53.52 \mathrm{TJ}$ & $55.82 \mathrm{TJ}$ \\
\hline
\end{tabular}

Achieved saving compared to the conventional superstructure implemented (masonry) is $55.82 \mathrm{TJ} /$ year from 2014 to 2021. Demand for the heating of rooftop extensions made 
from blocks and brick as per energy standards and directives of Slovakia is $64.62 \mathrm{TJ}$ for the period from 2014 to 2021. The heating demand of superstructures implemented with the SOLTAG 3 construction system (building with nearly zero energy needs) is $8.8 \mathrm{TJ}$. Total savings are $86.4 \%$.

The main positive aspect of SOLTAG 3 rooftop extensions is that these buildings are $\mathrm{CO}_{2}$ neutral. Their operation is covered by energy derived from the sun-through solar collectors (conversion of solar energy into heat) or photovoltaic panels (conversion of solar energy into electrical energy). In the case of a surplus of electricity, this energy is transmitted to the network or taken in the case of shortage. Comparative analysis of energy demand is in Table 6. Finally, we assume:

1. if (theoretically) all possible extensions are implemented (this year) using the standard (brick and blocks) method, we would have: $21,436,128 \mathrm{~m}^{2} \times 50 \mathrm{kWh} / \mathrm{m}^{2}=$ $1,071,806,400 \mathrm{kWh}=3858.5 \mathrm{TJ}$,

2. if (theoretically) all possible extensions are implemented by SOLTAG 1-low energy level, we would have: $21,436,128 \mathrm{~m}^{2} \times 30 \mathrm{kWh} / \mathrm{m}^{2}=643,083,840 \mathrm{kWh}=2315.1 \mathrm{TJ}-$ savings of $40 \%$ compared to conventional new buildings,

3. if (theoretically) all possible extensions are implemented by SOLTAG 2-passive level, we would have: $21,436,128 \mathrm{~m}^{2} \times 15.2 \mathrm{kWh} / \mathrm{m}^{2}=325,829,146 \mathrm{kWh}=1173 \mathrm{TJ}$-savings of $69.6 \%$ compared to conventional new buildings,

4. if (theoretically) all possible extensions are implemented by SOLTAG 3-buildings with nearly zero energy consumption, we would have: $21,436,128 \mathrm{~m}^{2} \times 4 \mathrm{kWh} / \mathrm{m}^{2}=$ $85,744,512 \mathrm{kWh}=308.7 \mathrm{TJ}$ —savings of $92 \%$ compared to conventional new buildings.

Table 6. Comparative analysis of energy demand.

\begin{tabular}{cccc}
\hline Technology & $\begin{array}{c}\text { Heat Energy } \\
\text { Demand (TJ) }\end{array}$ & Saving (\%) & $\begin{array}{c}\text { Saving by } \\
\text { Technology (TJ) }\end{array}$ \\
\hline Brick and blocks & 3858.5 & - & - \\
\hline Soltag 1 & 2315.10 & 40 & 1543.4 \\
\hline Soltag 2 & 1173 & 69.6 & 2685.5 \\
\hline Soltag 3 & 308.7 & 92 & 3549.8 \\
\hline
\end{tabular}

\subsection{Economic Return of SOLTAG Rooftop Extensions}

The energy benefits and energy savings by Soltag technology are considerable. Energy demand related to energy use for heating is lower for prefabricated. Soltag extensions than bricked extensions built according to existing Building Act of the Slovak Republic standards (see Table 7). SOLTAG extensions built with nearly zero energy consumption shows lower energy costs for heating about $194 €$. Interest rates are used to evaluate financial sources in the future. In this economic analysis, we decided to not use the interest rates of European Central Bank in this calculation, because the value of interest rate was very small and this small value does not have an influence on results.

Financial savings are presented in Table 7 related to individual types of SOLTAG 1 , SOLTAG 2, and SOLTAG 3 extensions. The best technology for financial saving is SOLTAG 3 extension. The calculations were based on an assumption that the particular extension will be constructed in the model area in Malacky town in the Bratislava region. Prices for heat supply were obtained directly from the heat supplier in this area. Costs related to the purchase of a building plot on the apartment building roof equal those of the bricked extension. This modular construction takes from five to eight working days, which substantially reduces the impact on the building's internal communications in contrast to the standard method (cca 20 to 30 working days). On the basis of experience from Denmark where several pilot projects have been implemented, we can state that the total construction costs of the Soltag building are 5 to $12 \%$ higher than a standard brick building. To enumerate the construction costs for a bricked extension on an apartment building, 
we need to know the value of the building plot in the locality, in our case in Malacky town: EUR 80.70 per $\mathrm{m}^{2}$ (from the value map of estate agencies in the Malacky District). We used the usable floor space of a housing unit of $84 \mathrm{~m}^{2}$ to calculate the overall costs for plot purchase of EUR 6778.80. Information, which was obtained from Ekonomické stavby, s.r.o. was used to estimate costs related to the construction of an extension using the standard walling method, where the turnkey project price has been determined at an average of EUR 1130.50 per $\mathrm{m}^{2}$ of usable floor space. The price includes costs related to project documentation, obtaining a building permit, construction, material, and the company's margin. Based on the overall dwelling area, we can determine the informative price of the apartment to be EUR 94,962, while the price together with the plot was EUR 101,740.80. Knowledge from the study of Soltag extension problems as part of the SUREFit (Sustainable Roof Extension Retrofit) project and practical experience from Denmark illustrates that a Soltag extension is on average $10 \%$ more expensive than a standard bricked extension. Hence, we can state that the estimated costs of the Soltag extension construction total EUR 1243.55 per $\mathrm{m}^{2}$. The total costs of the Soltag model house construction are EUR 104,458.20. Costs related to the purchase of a building plot on the apartment building roof equal those of the bricked extension.

Table 7. Financial savings related to heat demand for heating SOLTAG extensions.

\begin{tabular}{ccccc}
\hline & Bricked Extension & Soltag 1 & Soltag 2 & Soltag 3 \\
\hline Heat demand for heating & $50 \mathrm{kWh} / \mathrm{m}^{2}$ & $30 \mathrm{kWh} / \mathrm{m}^{2}$ & $15.2 \mathrm{kWh} / \mathrm{m}^{2}$ & $4 \mathrm{kWh} / \mathrm{m}^{2}$ \\
\hline Usable floor space of an apartment & $84 \mathrm{~m}^{2}$ & $84 \mathrm{~m}^{2}$ & $84 \mathrm{~m}^{2}$ & $84 \mathrm{~m}^{2}$ \\
\hline Annual heating demand & $4.200 \mathrm{kWh}$ & $2.520 \mathrm{kWh}$ & $1.277 \mathrm{kWh}$ & $336 \mathrm{kWh}$ \\
\hline Energy price-fixed component & $190.5388 \mathrm{EUR} / \mathrm{kW}$ & $190.5388 \mathrm{EUR} / \mathrm{kW}$ & $190.5388 \mathrm{EUR} / \mathrm{kW}$ & $190.5388 \mathrm{EUR} / \mathrm{kW}$ \\
\hline Energy price-variable component & $0.0502 \mathrm{EUR} / \mathrm{kWh}$ & $0.0502 \mathrm{EUR} / \mathrm{kWh}$ & $0.0502 \mathrm{EUR} / \mathrm{kWh}$ & $0.0502 \mathrm{EUR} / \mathrm{kWh}$ \\
\hline $\begin{array}{c}\text { Costs related to heat supply for } \\
\text { heating per year }\end{array}$ & EUR 210.84 & EUR 126.504 & EUR 64.09536 & EUR 16.8672 \\
\hline Costs for heating per year & EUR 401.3788 & EUR 317.0428 & EUR 254.63416 & EUR 207.406 \\
\hline Percentage saving & $/$ & $40 \%$ & $69.6 \%$ & 2685.5 \\
\hline Saving of energy (TJ) & $/$ & 1543.4 & 279.36 & 3549.8 \\
\hline Financial saving (EUR) per year & $/$ & 160.55 & 369.27 \\
\hline
\end{tabular}

In both extension types, it is necessary to consider the construction of an external building lift forming a communication connection with the adjacent street.

Economic page (see Figure 4) of SOLTAG 3 technology of rooftop extension is the best solution for energy saving and financial saving in the form of costs for heating. The total saving of energy costs by technology Soltag 3 by comparing with technology SOLTAG 1 is $200 €$ per year and saving of energy is $2006 \mathrm{TJ}$. All information means a total saving of $50 \%$. By the choice, technologies of SOLTAG for roof extension is important to accept two views-environmental and economic. An environmental point of view means energy saving and safety of the environment. An economical point of view means lower costs of energy and lower consumption of energy. The economical view consists of the costs of building and costs of energy consumption. Beginning building costs are very high, but the return of investment is shown in the costs of energy-saving, which are lower (see Table 8). 


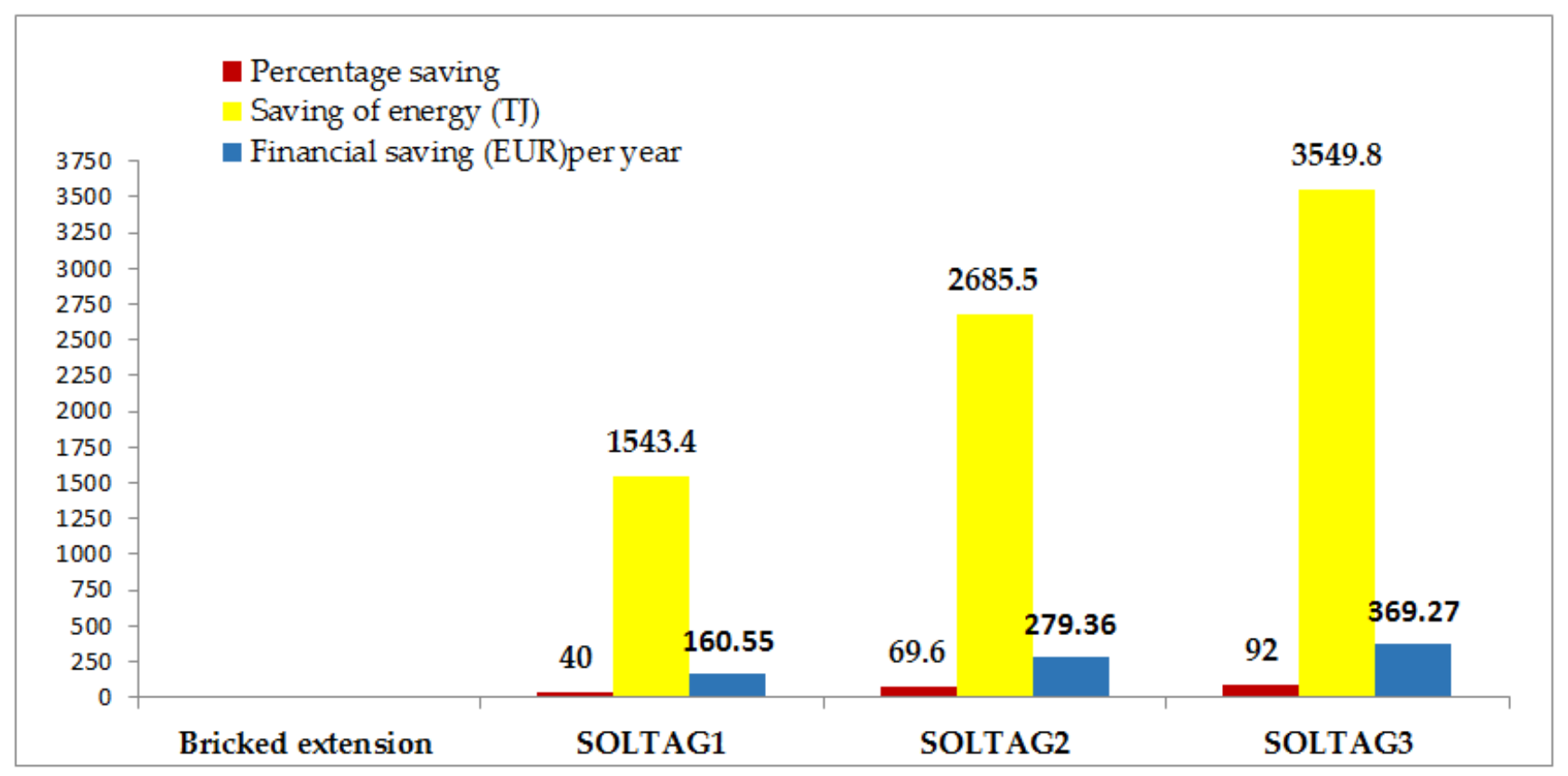

Figure 4. Total saving by technology SOLTAG.

Table 8. Estimated costs related to the construction of extension types.

\begin{tabular}{|c|c|c|c|c|c|c|}
\hline & \multicolumn{3}{|c|}{ Bricked Extension } & \multicolumn{3}{|c|}{ Soltag Extension } \\
\hline & $\begin{array}{l}\text { Costs Related to } \\
\text { Acquisition }\end{array}$ & Area & Costs & $\begin{array}{l}\text { Costs Related to } \\
\text { Acquisition }\end{array}$ & Area & Costs \\
\hline \multirow[t]{2}{*}{$\begin{array}{c}\text { Price of } \\
\text { construction }\end{array}$} & EUR $1130.50 / \mathrm{m}^{2}$ & $84 \mathrm{~m}^{2}$ & $\begin{array}{c}\text { EUR } \\
94,962\end{array}$ & EUR $1243.55 / \mathrm{m}^{2}$ & $84 \mathrm{~m}^{2}$ & EUR $104,458.20$ \\
\hline & \multicolumn{3}{|c|}{ Bricked Extension } & Soltag 1 & Soltag 2 & Soltag 3 \\
\hline $\begin{array}{c}\text { Price of } \\
\text { construction }\end{array}$ & \multicolumn{3}{|c|}{ EUR 94,962 } & EUR 104,458 & EUR 104,458 & EUR 104,458 \\
\hline $\begin{array}{l}\text { Costs for heating } \\
\text { per year }\end{array}$ & \multicolumn{3}{|c|}{ EUR 401} & EUR 317 & EUR 255 & EUR 207 \\
\hline Total costs & \multicolumn{3}{|c|}{ EUR 95,363 } & EUR 104,775 & EUR 104,713 & EUR 104,665 \\
\hline
\end{tabular}

Comparison of roof construction-by bricked extension and by using technology SOLTAG - shows that the technology using the bricked extension is cheaper. The variance between both technologies is so 9500 EUR. Heating cost per year is lower by using technology SOLTAG compared with technology by bricked extension about 194 EUR. The total cost of construction and cost for heating are the best by using the technology of bricked extension. Even through results we can prefer technology by Soltag because it means environmental advantage and lower energy costs during using this construction (see Figure 5). In this case, the economic return is 23 years that means the optimal time period of return of investment for the Soltag technology. 


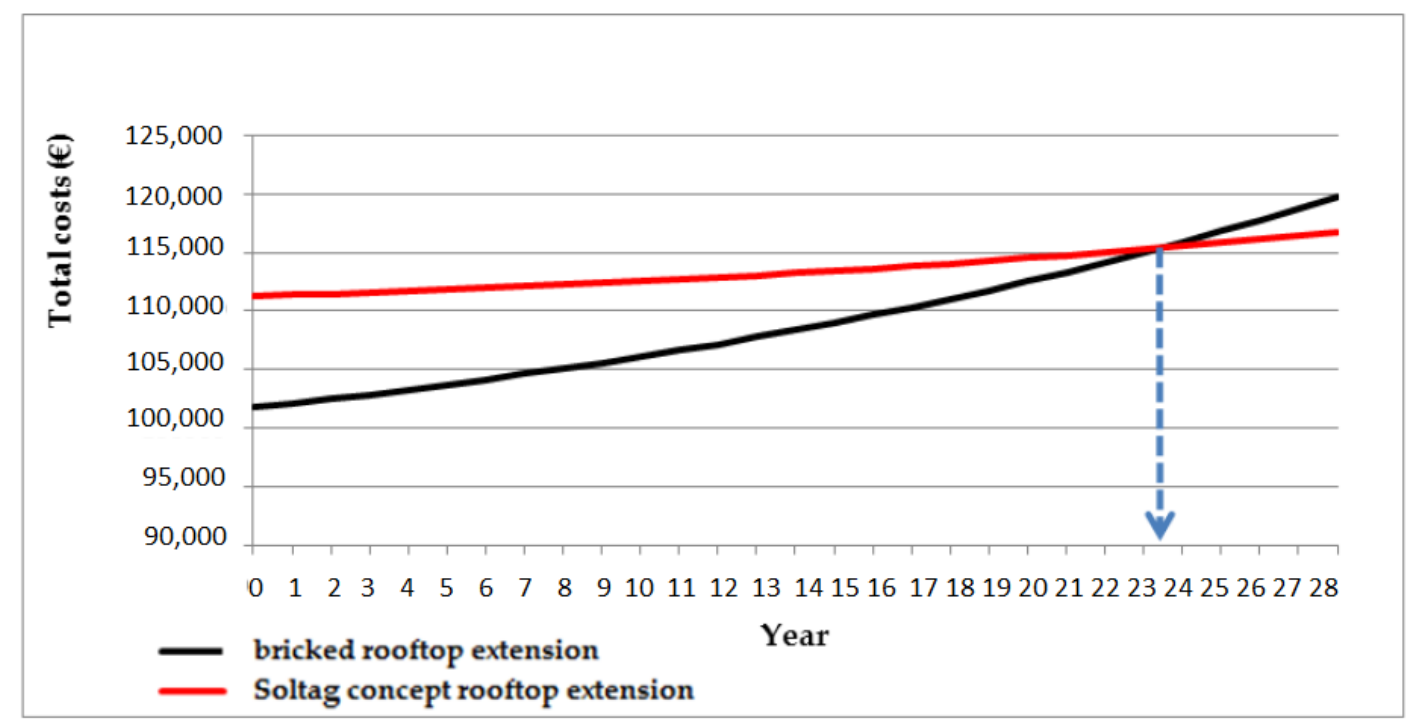

Figure 5. Economic return.

Total costs estimated related to the construction of extension by bricked technology have increased since the moment of the roof extension and the construction of the housing unit. Those costs have an increasing trend that consists of an increase in the prices of materials. This type of technology is out of date; it needs financial resources that are cheaper than financial resources for SOLTAG technology. Total costs estimated related to the construction of extension by SOLTAG technology have increasing step by step since the moment of the roof extension and the construction of the housing unit. Those costs have an increasing trend that consists of high prices of materials and new technology. This type of technology is new and innovative; it needs high financial resources at the beginning of construction that are gradually harmonized and equal.

The breakthrough period is the 23 years of use of the dwelling, where the total costs of SOLTAG technology are gradually decreasing and the costs of brick construction technology are increasing. This extremely reflects the fact that it is advisable to invest funds at the beginning of the decision-making process to technology SOLTAG, where the economic return after 23 years of use of the housing is reflected, and that total costs gradually are decreasing (see Figure 6).

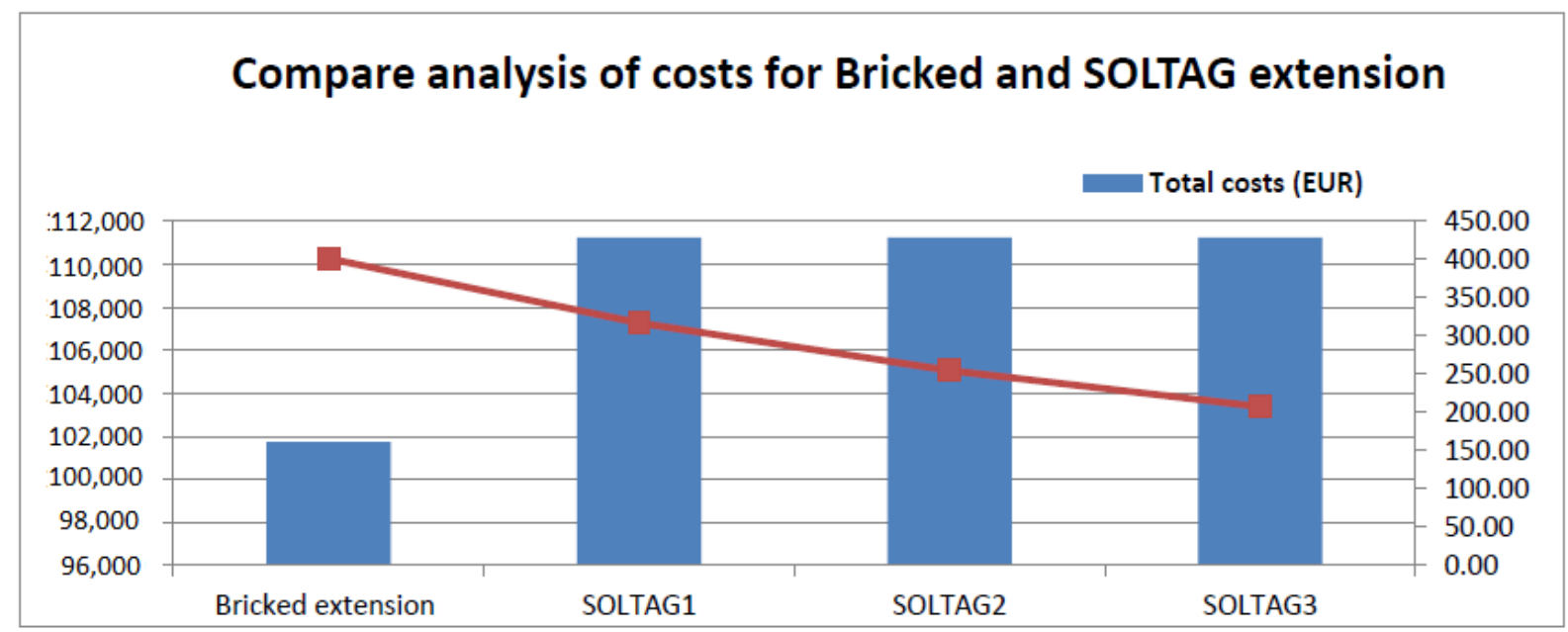

Figure 6. Comparison of analysis of costs. 
The economic efficiency of the chosen technology is determined mainly by the amount of costs that need to be invested in the residential building at the beginning of the construction and the costs that arise during the use of the residential building. In addition to operating costs, energy costs and their annual consumption, which are the lowest in SOLTAG 3 technology, play an important role, and overall the low consumption of SOLTAG technology. With SOLTAG technology, there is a visible downward trend in unit cost per year for energy consumption and a high overall cost at the start of the construction period.

\section{Conclusions}

In this article, we dealt with suggesting a solution for low-energy extensions-the SOLTAG concept - on the basis of knowledge acquired by studying problems related to Soltag extensions as part of the SURE-Fit (Sustainable Roof Extension Retrofit) project. The main aim of this paper was to assess energy savings and economic benefits for three rooftop extensions of the SOLTAG concept and bricked extensions for a model area in the Slovak Republic.

With the assessment and comparison of energy saving of three types of the prefabricated system of SOLTAG 1 (low energy level), SOLTAG 2 (passive level), and SOLTAG 3 (nearly zero energy needs) and based on the comparison of their costs with the normalized standards by law, we can observe proven economic, environmental, financial benefits of this technology. The variant SOLTAG 3 seems the best solution for energy saving and financial savings in the form of costs for heating. The initial building costs are very high, but the return on investments is presented in costs on energy saving for 23 years. We assume that further lowering of costs on energy for rooftop systems SOLTAG should be achieved with the installation of solar collectors. That concept of the SOLTAG can be used in various buildings in various places. Using this SOLTAG technology is possible worldwide.

Author Contributions: All authors contributed equally to this work. Methodology and data curation, D.S. and R.J.; formal analysis and writing - review and editing, D.S., K.T., and S.H. All authors have read and agreed to the published version of the manuscript.

Funding: This research received no external funding.

Institutional Review Board Statement: Not applicable.

Informed Consent Statement: Informed consent was obtained from all subjects.

Data Availability Statement: Data sharing is not applicable to this article.

Acknowledgments: This paper was supported by Slovak Research and Development Agency under the grants VEGA No. 1/0604/18 Economic Aspects of Sustainable Construction within Intelligent Urban Structures.

Conflicts of Interest: The authors declare no conflict of interest.

\section{References}

1. World Energy Scenarios. Composing Energy Futures to 2050; World Energy Council: London, UK, 2014.

2. Janicek, F.; Darula, I.; Gadus, J.; Regula, E.; Smitkova, M.; Polonec, L.; Ludvik, J.; Kubica, J.; Michalik, M.; Bindzar, M. Renewable Energy Sources 1, 1st ed.; Faculty of Electrical Engineering and Information Technology, Slovak University of Technology: Bratislava, Slovakia, 2009.

3. Fritsch, A.; Gallimore, P. Healing Appalachia: Sustainable Living through Appropriate Technology; The University Press of Kentucky: Lexington, KY, USA, 2007.

4. Newton, C.; Backhouse, S.; Aibinu, A.A.; Cleveland, B.; Robert, H. Crawford ID, Dominik Holzer, Philippa Soccio and Thomas Kvan: Plug and Play: Future Prefab for Smart Green Schools. Buildings 2018, 8, 88. [CrossRef]

5. Snell, C.; Callahan, T. Building Green: A Complete How-to Guide to Alternative Building Methods: Earth Plaster, Straw Bale, Cordwood, Cob, Living Roofs; Lark Books, A Division of Sterling Publishing Co: New York, NY, USA, 2005.

6. Spirkova, D.; Caganova, D. Smart Housing in Sustainable Development. Summit Rim, Conference Proceedings EAI; Springer: Berlin/Heidelberg, Germany, 2015. 
7. World Economic Forum. The Global Competitiveness Report 2010-2011. Available online: http://www3.weforum.org/docs / WEF_GlobalCompetitivenessReport_2010-11.pdf (accessed on 27 December 2020).

8. Szekeres, K. Roof Top Extensions for Multifamily Houses in Slovakia. Slovak J. Civil Eng. 2010, 18, 17-23. [CrossRef]

9. Spirkova, D.; Ivanicka, K.; Zubkova, M. Economic Aspects of Sustainable Development of Built Environment in Europe, 1st ed.; MCDP International UG: Frankfurt am Main, Germany, 2013.

10. Lawson, M.; Ogden, R.; Goodier, C.H. Design in Modular Construction; CRC Press: Boca Raton, FL, USA; Taylor \& Francis Group: Abingdon, UK, 2014.

11. SOLTAG-Energy Housing. Available online: https://www.buildup.eu/sites/default/files/content/Soltag\%5B1\%5D.pdf (accessed on 5 April 2020).

12. Slovak Technical Standards (STN) 73 0540-3, Properties of environment and building products-Parts 3: Thermal performance of buildings and constructions. Thermal protection of buildings. Slovak Office of Standards, Metrology and Testing. Available online: https: / www.unms.sk/?home (accessed on 25 June 2020).

13. Slovak Technical Standards (STN) 73 0540-4, Calculation Methods-Parts 4: Thermal Performance of Buildings and Constructions. Thermal Protection of Buildings. Bratislava, Slovak Office of Standards, Metrology and Testing. Available online: https: / / www.unms.sk/?home (accessed on 25 June 2020).

14. Slovak Technical Standards (STN) 73 0540-2, Functional Requirements-Parts 2: Thermal Performance of Buildings and Constructions. Thermal Protection of Buildings. Slovak Office of Standards, Metrology and Testing, Slovak Republic. Available online: https:/ / www.unms.sk/?home (accessed on 25 June 2020).

15. Janiss, R. Housing Policy Instruments for Promotion of Sustainable Development of Housing Fund. Ph.D. Thesis, Slovak University of Technology, Bratislava, Slovakia, 2014.

16. The Act. No. 555/2005 on the Energy Performance of Buildings and on the Amendments to Certain Laws Ministry of Transport and Construction of the Slovak Republic. Available online: https:/ /www.buildup.eu/en/practices/publications/slovak-republicact-n-5552005-coll-energy-performance-buildings-and (accessed on 25 June 2020). 